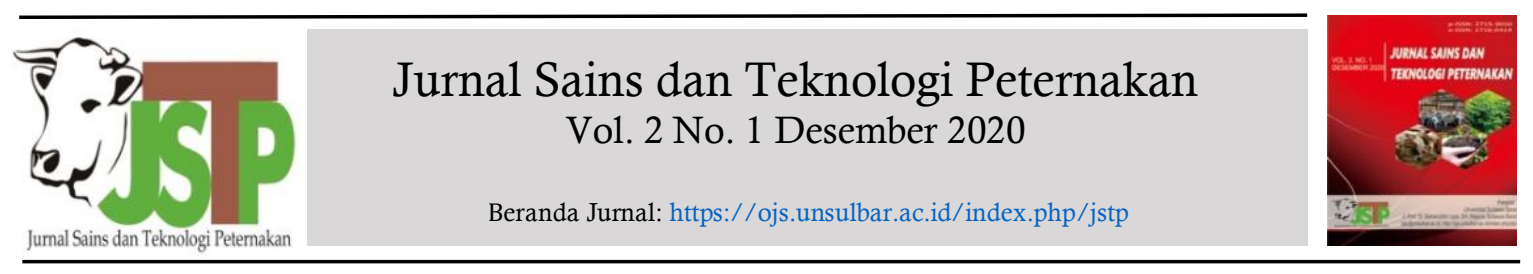

\title{
Growth of Odot Grass (Pennisetum purpureum cv. Mott) on Sandy Marginal Land on Payung Island Kepulauan Seribu Jakarta
}

\author{
(Pertumbuhan Rumput Odot (Pennisetum purpureum cv. Mott) pada Lahan Marjinal Berpasir di Pulau \\ Payung Kepulauan Seribu Jakarta) \\ Syamsu Bahar ${ }^{1^{*}}$, A. Saenab ${ }^{1}$, N. Riris Sudolar ${ }^{1}$ \\ ${ }^{1}$ Jakarta Assessment Institute for Agricultural Technology (Balai Pengkajian Teknologi Pertanian Jakarta) Jl. \\ Ragunan No. 30 Pasar Minggu, Jakarta 12540.
}

\section{A R T I C L E I N F O}

Received: 6 November 2020

Accepted: 22 Desember 2020

*Corresponding author

syamsubahar@yahoo.com

Keywords:

Fertilization

Odot grass

Sandy marginal land

\begin{abstract}
A B S T R A C T
Odot grass (Pennisetum purpureum cv. Mott) is a potential forage to be developed in order to guarantee goats feed in Payung island, Kepulauan Seribu Regency, DKI Jakarta province. The purpose of this study was to determine the effect of fertilizer treatment on growth and forage production odot grasses, namely the treatment of organic fertilizer in the form of goat urine and the treatment of commercial inorganic fertilizers, namely NPK fertilizer.This study was in the form of a field trial using a randomized block design with three treatments and six replications. The treatments were 1) Goat urine fertilizer $500 \mathrm{ml}$ per clump; 2) NPK fertilizer 5 grams per clump and 3) Control (without fertilizer). Goat urine was taken from the location of the goat pen that has been stored for two months fermentation increased nutrient quality. Fertilization with goat urine organic fertilizer on odot grass gave vegetative growth and forage production responses as well as the use of NPK commercial inorganic fertilizers.
\end{abstract}

\section{A B S T R A K}

$\overline{\text { Rumput odot (Pennisetum purpureum cv. Mott) merupakan hijauan }}$ pakan ternak kambing yang sangat potensial untuk dikembangkan agar dapat menjamin ketersediaan pakan kambing di Pulau Payung, Kabupaten Kepulauan Seribu, Provinsi DKI Jakarta. Tujuan penelitian ini untuk mengetahui pengaruh perlakuan pemberian pupuk terhadap pertumbuhan dan produksi hijauan rumput odot dengan perlakuan pemberian pupuk organik berupa urin kambing dan pemberian pupuk an-organik komersil NPK. Penelitian ini berupa percobaan lapangan menggunakan Rancangan Acak Kelompok (RAK) dengan tiga perlakuan dan enam kelompok. Perlakuan tersebut adalah: 1) Pupuk urin kambing $500 \mathrm{ml}$ per rumpun; 2) Pupuk NPK 5 gram per rumpun, dan 3) Kontrol (tanpa pupuk). Urin kambing yang digunakan diambil dari lokasi kandang kambing yang sudah disimpan selama dua bulan masa fermentasi untuk meningkatkan kualitas hara. Pemupukan dengan pupuk organik urin kambing pada rumput odot memberikan respon pertumbuhan vegetatif dan produksi hijauan yang sama baiknya dengan penggunaan pupuk komersial NPK an-organik.
Kata Kunci:

Pemupukan

Rumput odot

Lahan Marjinal
p-ISSN: 2715-3010 | e-ISSN: 2716-0424 


\section{Introduction}

Odot grass (Pennisetum purpureum cv. Mott) is one of the varieties of elephant grass, abroad often known as Dwarf Elephant Grass or Mott Elephant Grass. This odot grass is another name in Indonesian is dwarf elephant grass or mini elephant grass, but in most classes of goat and sheep breeders better known as odots. The vegetative part of the leaves and stems of the grass feels softer so that it is favored by goats and sheep (Sarwanto \& Tuswati, 2017) and available of goat feed (Kaca, Suariani, Suwitari, \& Sanjaya, 2019). Odot grass can grow on marginal sandy land with good fertilization. Fertilization problems need to find an alternative to cheap fertilizers so as to reduce production costs. One way that can be reached is by fertilizing using goat urine organic fertilizer (Syamsuddin, 2016). The presence of goats will contribute to fertilizer in an integrated manner for odot grass and vice versa odot grass can grow and develop for goat feed. To breed grass can be done by vegetative methods, which is replanting with stems or using branching samplings that grow best (Sirait, 2017). Cutting on these branches is done with a tool that can be used to cut on the stem, cutting is done on the stem which will become plant material (Noorrohmah, Al Hafiizh, \& Ermayanti, 2017), cuttings with a length of approximately 15-30 cm (Djufri, 2016) and planting space varies $50 \times 80 \mathrm{~cm}$ (Hidayanto, Astuti, \& Amin, 2019), $80 \times 80 \mathrm{~cm}$ (Kusdiana, Hadist, \& Herawati, 2017), $75 \times 35 \mathrm{~cm}$ (Hendarto, Qohar, Hidayat, Bahrun, \& Harwanto, 2020). Odot grass is first harvested since it is planted at the age of 70-80 days. Some characteristics that can be shown when the grass is available for the stem segment has reached a size of $15 \mathrm{~cm}$. For the next harvest age can be 35 - 45 days in the rainy season or 40-50 days in the dry season. It also depending on the conditions can be between 60 - 90 days (Pratama, 2018).

Thousand Islands is a group of small islands stretching from the Bay of Jakarta to a group of islands around the bay with an ocean area of $6,997.50 \mathrm{~km}^{2}$ and an area of $8.76 \mathrm{~km}^{2}$. The island consists of 110 islands and consists of 11 income islands, namely islands, then 9 public tourism islands, 36 other tourist islands and 2 islands are Nature Reserve islands. The population of the Thousand Islands is 20,376 people with an average growth of $1.101 \%$, most of the people's livelihoods are fishermen. The average air temperature in the Thousand Islands between $28.43-28.9^{\circ} \mathrm{C}$ and relatively high humidity that is $76.52 \%$ (BPS, 2020).
Land in small islands in Kepulauan Seribu District, DKI Jakarta Province, which is predominantly sandy texture, is classified as marginal land for the cultivation of cash crop plants which is minimal and does not hold air well. Water that is poured into plants will quickly absorb so that the plants dry quickly. The condition of sandy soil that is multiplied as marginal land for crop cultivation. According to Saputro (2015) that sand soil is soil that contains very little clay, dust and nutrients. It is planned that the sand will easily drain the air, around 150 $\mathrm{cm}$ per hour. Expected, the ability of the soil to store water is very low, which is $1.6-3 \%$ of the total available air.

The use of goat urine as organic fertilizer on odot grass is to take advantage of local resources that are available and cheap compared to buying inorganic fertilizers which are expensive, especially when their availability is sometimes limited and difficult to obtain. The aim of this study was to determine the effect of fertilizer treatment on growth and forage production odot grasses, namely the treatment of organic fertilizer in the form of goat urine and the treatment of commercial inorganic fertilizers, namely NPK fertilizer.

\section{Material and Methods}

\subsection{Land Preparing}

Processing in sandy soil was quite easy due to the light texture of the soil so that it was easily processed using a hand tractor. The land was processed twice and once to flatten and make trenches and plot boundaries.

\subsection{Materials}

Odot grass was introduced as one of the goat's forage feed. Before planting the odot grass was done tillage. Anglo Nubian x Etawa was goat cross breed (Aziz, Atabany, \& Praharani, 2018) these goat introduced on Payung Island. Liquid manure of goat urine used wasthe urine that has been allowed to stand for 2 months. The composition of urine and water was 1 litre of goat urine mixed with 4 litre of water so that the amount of 5 litre was given for 10 clumps of odot grass plants or $500 \mathrm{ml}$ per clump. Commercial NPK fertilizer that was prepared was commercial fertilizer with a certain brand that is given as much as 5 grams for 1 clump of odot grass was given once during the experiment. 


\subsection{Experimental Design}

This experiment used 3 treatments and 6 replications in randomized block design with blocking soil elevation. The treatments were 1) Treatment of goat urine fertilizer; 2) Treatment of NPK fertilizer and 3) Control (without fertilizer). The area used was $\pm 200 \mathrm{~m}^{2}$. The size of one plot was $2 \mathrm{~m} \times 5 \mathrm{~m}$, the spacing of grass $0.5 \mathrm{~m} \times 1 \mathrm{~m}$ with one cutting per hole. For maintenance, replanting dead plants and watering daily.

\subsection{Collection and Data Analysis}

Data collection on odot grass after 60 days of treatments include: 1) number of tillers, counting the number of tillers in one clump; 2) number of leaves, counting the number of leaves in one clump; 3) leaf length; calculate the length of the leaves in one clump and 4) fresh forage production, weigh forage in one clump. Observations were made by counting the number of tillers, the number of leaves and the length of leaves in one clump of odot grass plants, and the production of fresh forages. Data collected were analyzed by analysis of variance and follewed by the LSD test (La Daha, 2011).

\section{Result and Discussion}

Goat urine organic ferlitizer showed that significant differences on the number of tillers, number of leaves, leaf length and forage production were presented in Table 1. The effect of goat urine organic fertilizer compared to NPK inorganic fertilizers on the number of odot grass tillers, while the effect of both compared with the control shows a real difference. Goat urine organic fertilizer is as useful as NPK inorganic fertilizer, which is to increase the number of odot tillers from an average of two puppies per clump in the control treatment to an average of 6 puppies per clump in the treatment of goat urine fertilization and an average of 6 tillers NPK fertilization treatment.

Table 1. Effect of fertilizer type treatment on number of tillers, number of leaves, leaf length and forage production of odot grasses

\begin{tabular}{lcccc}
\hline Treatments & $\begin{array}{c}\text { Number of } \\
\text { tillers (bud) }\end{array}$ & $\begin{array}{c}\text { Number of } \\
\text { leaves (blade) }\end{array}$ & $\begin{array}{c}\text { Leaf length } \\
(\mathrm{cm})\end{array}$ & $\begin{array}{c}\text { Forage } \\
\text { production } \\
\left(\mathrm{kg} / 100 \mathrm{~m}^{2}\right)\end{array}$ \\
\hline Goat urine organic fertilizer & $6.6 \pm 3.7^{\mathrm{b}}$ & $37.7 \pm 12.6^{\mathrm{b}}$ & $50.7 \pm 4.3^{\mathrm{b}}$ & $16.16^{\mathrm{b}}$ \\
NPK inorganic fertilizers & $6.1 \pm 2.9^{\mathrm{b}}$ & $45.3 \pm 21.1^{\mathrm{c}}$ & $41.2 \pm 4.8^{\mathrm{a}}$ & $16.66^{\mathrm{b}}$ \\
Control (without fertilizer) & $2.8 \pm 1.5^{\mathrm{a}}$ & $22.7 \pm 9.7^{\mathrm{a}}$ & $40.3 \pm 8.0^{\mathrm{a}}$ & $9.66^{\mathrm{a}}$ \\
\hline
\end{tabular}

Note: The superscript in the same column show significant differences $(\mathrm{P}<0.05)$

Table 1, showed that the effect of fertilizer treatments using goat urine organic fertilizer compared with NPK inorganic fertilizer not significant difference on number of tillers and forage production, while number of leaves and length showed significant difference. This mean that goat urine organic fertilizer can be used as an alternative to fertilizing odot grass. Susmita, Kalsum, \& Wadjdi (2019) argues that organic fertilization increases forage production.

The effect of goat urine organic fertilizer compared with NPK inorganic fertilizers and compared with control on odot grass leaf length was significantly different, while the effect of NPK inorganic fertilizer compared with control showed no real effect. Goat urine organic fertilizer increases the length of leaves of odot grass from an average of $40 \mathrm{~cm}$ in leaf length per clump in the control treatment to an average of $50 \mathrm{~cm}$ in leaf length per clump in goat urine treatment. According to Syamsuddin (2016) the use of liquid organic fertilizer of fermented goat urine can improve the growth of mini elephant grass in dry-critical land by $120 \mathrm{ml} /$ plot $\left(10 \mathrm{~m}^{2}\right)$. According to Kurniawan, Ginting, \& Nurjannah (2017) NPK content in $300 \mathrm{ml}$ goats urine fertilizer urine nitrogen $0.69 \%$, phosphor $2.09 \%$ and potassium $0.64 \%$. The same thing nutrient content was reported by Allwar \& Pranata (2013).

The effect of goat urine organic fertilizer compared with NPK inorganic fertilizer on odot grass forage production was not significantly different, while the effect of both compared with control showed a real difference. Goat urine organic fertilizer is as useful as NPK inorganic fertilizer, which is to increase the production of odot grasses from an average of $9 \mathrm{~kg} / 100 \mathrm{~m}^{2}$ per clump in the control treatment to an average of $16 \mathrm{~kg} / 100 \mathrm{~m}^{2}$ per clump in the urine treatment of goats and is flat average $16 \mathrm{~kg} / 100 \mathrm{~m}^{2}$ in NPK treatment.

The growth and production of odot grass will be higher. According to Sarwanto \& Tuswati (2017) the provision of compost of goat manure as much as $1.6 \mathrm{~kg} / \mathrm{m}^{2}$ showed significantly better 
results on the growth and forage production of dwarf elephant grass in the former limestone quarry. The same thing was reported by Abdullah, Budhie, \& Lubis (2011); Rifai, Rianto, \& Susilowati (2018); Hadirin, Hanafi, Rahmawati, \& Sadeli (2019); Purnamasari \& Zulfarosda (2019).

This study also conducted a composite samples all treatment of odot forage grass to further proximate analysis (Table 2) in a laboratory to determine the nutrient content of odot forage grass. The results of the odot grass nutrient analysis show that the crude protein content is quite high at around $21 \%$. The content of feed protein is one of the references to the quality level of a type of feed.

Tabel 2. Proximate analysis of odot grass nutrient content

\begin{tabular}{lcccccccc}
\hline Forage & $\begin{array}{c}\text { Water } \\
\text { content } \\
\mathrm{g} / 100 \mathrm{~g}\end{array}$ & $\begin{array}{c}\text { Crude } \\
\text { Protein } \\
\mathrm{g} / 100 \mathrm{~g}\end{array}$ & Fat g/100 g & $\begin{array}{c}\text { Energy } \\
\text { Kcal/kg }\end{array}$ & $\begin{array}{c}\text { Fiber } \\
\mathrm{g} / 100 \mathrm{~g}\end{array}$ & $\begin{array}{c}\text { Ash } \\
\mathrm{g} / 100 \mathrm{~g}\end{array}$ & $\begin{array}{c}\mathrm{Ca} \\
\mathrm{g} / 100 \mathrm{~g}\end{array}$ & $\begin{array}{c}\mathrm{P} \\
\mathrm{g} / 100 \mathrm{~g}\end{array}$ \\
\hline Odot grass & 8.39 & 21.16 & 4.02 & 3370 & 26.64 & 16.62 & 0.95 & 0.34 \\
\hline
\end{tabular}

Note: This data only applies to sample snippets sent to laboratories. Balitnak Ciawi, West Java.

\section{Conclusion}

Fertilization with goat urine organic fertilizer on odot grass responds to vegetative growth and forage production as well as the use of NPK commercial inorganic fertilizers.

\section{References}

Abdullah, L., Budhie, D. D. S., \& Lubis, A. D. (2011). Pengaruh aplikasi urin kambing dan pupuk cair organik komersial terhadap beberapa parameter agronomi pada tanaman pakan Indigofera Sp. Pastura: Journal of Tropical Forage Science, 1(1), 5-8. https://doi.org/10.24843/Pastura.2011.v0 1.i01.p02

Allwar, \& Pranata, N. E. (2013). Pemanfaatan urine ternak dalam pembuatan pupuk cair untuk menambah nilai guna pada limbah. Jurnal Inovasi dan Kewirausahaan, 2(1), 6872.

Aziz, S. A., Atabany, A., \& Praharani, L. (2018). Produksi dan kualitas susu kambing persilangan Anglo Nubian dan kambing PE. IPB University.

BPS. (2020). Badan Pusat Statistik Kabupaten Kepulauan Seribu. Retrieved from https://kepulauanseribukab.bps.go.id/pub likasi.html

Djufri. (2016). Potensi padang rumput (Grasland) sebagai peluang usaha prospektif belum dimanfaatkan secara optimal. In S. M. E. Susilowati, Karman, Y. Vitner, D. A. J. Selanno, S. Mursito, R. Koneri, \& Mudatsir (Eds.), Prosiding Seminar Nasional Biotik 2016: Pendidikan Berbasis Bio-Enterpreneurship dan Pelestarian Sumberdaya Alam Hayati dalam Mempersiapkan Sumber Daya Manusia pada
Era Masyarakat Ekonomi Asean (MEA) (Vol. 3, pp. 6-19). Banda Aceh: Program Studi Pendidikan Biologi Fakultas Tarbiyah dan Keguruan Universitas Islam Negeri ArRaniry.

Hadirin, Hanafi, N., Rahmawati, N., \& Sadeli, A. (2019). Respon hijauan dengan pemberian urin kambing fermentasi. Jurnal Peternakan Nusantara, 5(1), 21-30.

Hendarto, E., Qohar, A. F., Hidayat, N., Bahrun, \& Harwanto. (2020). Produksi dan daya tampung rumput Odot (Pennisetum purpureum cv. Mott) pada berbagai kombinasi pupuk kandang dan NPK. Prosiding Seminar Teknologi dan Agribisnis Peternakan VII-Webinar: Prospek Peternakan Di Era Normal Baru Pasca Pandemi COVID19, 7, 751-758. Purwokerto: Fakultas Peternakan Universitas Jenderal Soedirman.

Hidayanto, D., Astuti, N., \& Amin, L. (2019). Pengaruh jarak tanam terhadap Ppoduktivitas defoliasi pertama rumput Odot (Pennisetum purpureum cv. Mott). Universitas Mercu Buana.

Kaca, I. N., Suariani, L., Suwitari, N. K. E., \& Sanjaya, I. G. A. M. P. (2019). Budidaya rumput odot di Desa Sulangai Kecamatan Petang Kabupaten Badung - Bali. Community Service Journal (CSJ), 2(1), 2933.

Kurniawan, E., Ginting, Z., \& Nurjannah, P. (2017). Pemanfaatan urine kambing pada pembuatan pupuk organik cair terhadap kualitas unsur hara makro (NPK). Prosiding Seminar Nasional Sains dan Teknologi (SEMNASTEK), 1-10. Jakarta: Fakultas Teknik Universitas Muhammadiyah 
Jakarta.

Kusdiana, D., Hadist, I., \& Herawati, E. (2017). Pengaruh jarak tanaman terhadap tnggi tanaman dan berat segar per rumpun rumput gajah odot (Pennisetum purpureum cv. Mott). Jurnal Ilmu Peternakan (JANHUS), 1(2), 32-37.

La Daha. (2011). Rancangan Percobaan untuk Bidang Biologi dan Pertanian: Teori dan Aplikasinya. Makassar: Masagena Press.

Noorrohmah, S., Al Hafiizh, E., \& Ermayanti, T. M. (2017). Induksi dan proliferasi kalus rumput odot (Pennisetum purpureum cv. Mott). Prosiding Seminar Nasional Fakultas Pertanian Universitas Nasional, 371-384. Bogor: Pusat Penelitian Bioteknologi LIPI.

Pratama, D. (2018). Keragaman kualitas rumput Odot (Pennisetum purpureum cv. Mott) berdasarkan umur pemotongan yang dibudidayakan oleh petani di Kecamatan Ngajum Kabupaten Malang. Universitas Brawijaya.

Purnamasari, R. T., \& Zulfarosda, R. (2019). Pengaruh dosis fermentasi urin kambing terhadap pertumbuhan dan hasil tanaman buncis (Phaseolus vulgaris L.). Gontor AGROTECH Science Journal, 5(1), 73-86. https://doi.org/10.21111/agrotech.v5i1.3 101

Rifai, A., Rianto, H., \& Susilowati, Y. E. (2018). Pengaruh pemberian macam media dan macam urin terhadap hasil tanaman stroberi (Fragaria ananassa). VIGOR: Jurnal Ilmu Pertanian Tropika dan Subtropika, 3(1), $1-4$.

Saputro, T. E. (2015). Agriculture research center di lahan pasir pantai baru Yogyakarta (dengan pendekatan Green Architecture). Universitas Muhammadiyah Surakarta.

Sarwanto, D., \& Tuswati, S. E. (2017). Pertumbuhan rumput Gajah kerdil (Pennisetum purpureum 'Mott') di lahan terbuka bekas penambangan batu kapur kawasan karst Gombong Jawa Tengah. Majalah Ilmiah Biologi BIOSFERA: A Scientific Journal, 34(3), 131-137. https:// doi.org/10.20884/1.mib.2017.34.3.502

Sirait, J. (2017). Rumput Gajah Mini (Pennisetum purpureum cv. Mott) sebagai hijauan pakan untuk ruminansia. Wartazoa, 27(4), 167176. https://doi.org/10.14334/wartazoa. v27i4.1569 167
Susmita, S. L., Kalsum, U., \& Wadjdi, M. F. (2019). Pengaruh frekuensi pemupukan biourin pada rumput odot (Pennisetum purpureum $\mathrm{cv}$. Mott) terhadap kandungan bahan kering, NDF, dan ADF. Jurnal Rekasatwa Peternakan, 1(1), 67-70.

Syamsuddin, S. N. (2016). Pertumbuhan kembali (regrowth) rumput gajah mini (Pennisetum purpureum cv. Mott) melalui pemberian pupuk organik cair pada lahan kering-kritis. Universitas Hasanuddin, Makassar. 